ARTICLE

DOI: $10.1038 / s 41467-017-00020-1$

\title{
Rotiferan Hox genes give new insights into the evolution of metazoan bodyplans
}

\author{
Andreas C. Fröbius ${ }^{1} \&$ Peter Funch (iD ${ }^{2}$
}

The phylum Rotifera consists of minuscule, nonsegmented animals with a unique body plan and an unresolved phylogenetic position. The presence of pharyngeal articulated jaws supports an inclusion in Gnathifera nested in the Spiralia. Comparison of Hox genes, involved in animal body plan patterning, can be used to infer phylogenetic relationships. Here, we report the expression of five Hox genes during embryogenesis of the rotifer Brachionus manjavacas and show how these genes define different functional components of the nervous system and not the usual bilaterian staggered expression along the anteroposterior axis. Sequence analysis revealed that the lox5-parapeptide, a key signature in lophotrochozoan and platyhelminthean Hox6/lox5 genes, is absent and replaced by different signatures in Rotifera and Chaetognatha, and that the MedPost gene, until now unique to Chaetognatha, is also present in rotifers. Collectively, our results support an inclusion of chaetognaths in gnathiferans and Gnathifera as sister group to the remaining spiralians.

\footnotetext{
${ }^{1}$ Institut für Allgemeine und Spezielle Zoologie, Abteilung Entwicklungsbiologie, Justus-Liebig-Universität Gießen, Stephanstraße 24, 35390 Gießen, Germany. ${ }^{2}$ Department of Bioscience, Aarhus University, Ny Munkegade 116, DK- 8000 Aarhus C, Denmark. Correspondence and requests for materials should be addressed to A.C.F. (email: andreas.froebius@gmail.com)
} 
O riginally discovered in Drosophila melanogaster 1,2 , Hox gene transcription factors have been researched extensively in a phylogenetically diverse range of animals over the last 30 years. Being present in the genomes of nearly all animals with exception of Porifera, Ctenophora, and Placozoa, this family of highly conserved transcriptional regulators controls some of the most fundamental processes of embryonic development. During morphogenesis of all triploblastic metazoans studied, Hox genes exhibit expression in body regions along the antero-posterior axis of the embryo at some point. Regional identities are imprinted by either single or combined expression of different Hox genes, referred to as "Hox code". This is clearly seen in the segmented taxa Arthropoda ${ }^{3}$, Annelida ${ }^{4}$, 5 , and Chordata $^{6,7}$ where the exact identity of body segments is regulated by the "Hox code". Here, deviations from the appropriate expression profiles result in homeotic transformations of the body regions involved. Amazingly, even across distantly related taxa, body regions comparable to each other (anterior, median, posterior) are patterned by orthologous Hox genes. Thus, evolutionary changes of Hox gene expression may have led to evolutionary shifts accounting for the emergence of new body plans ${ }^{8}$. Having arisen by tandem duplication, Hox genes are often physically linked in genomic clusters. A correlation of the spatial order of Hox gene expression along a primary body axis and sometimes even temporal order of Hox gene activation during embryogenesis with the order of the genes in the Hox cluster, referred to as colinearity ${ }^{9}$, has been observed in a broad range of metazoans. In some bilaterian taxa, however, the Hox cluster has been rearranged ${ }^{10}$ or even dispersed up to the relocation of all Hox genes to different locations of the genome ${ }^{11,12}$. Degradation of the Hox cluster, however, does not necessarily result in destruction of the Hox code. In some cases, specification of appropriate body regions is maintained in taxa where Hox genes are no longer closely linked ${ }^{13,14}$.

Within Protostomia, Hox gene expression has been studied in a variety of ecdysozoan and spiralian taxa. However, Hox gene activation during embryonic development has not been studied in gnathiferans so far. Based on morphological characters, it has been proposed that the phylum Rotifera including the parasitic Acanthocephala, along with Gnathostomulida and Micrognathozoa, form the clade Gnathifera ${ }^{15-17}$. Rotifers are microscopic, ecologically important aquatic animals comprising ca. 2200 described species. Their embryonic development and sexual dimorphic adult body plans exhibit special features. Protected within an egg shell, development starts with a unique cleavage pattern involving an exceptional type of $\mathrm{D}$-quadrant cleavage $^{18-20}$. Lacking a larval form, direct development with early determination gives rise to eutelic animals typically with a tripartite, pseudocoelomic body plan, consisting of a head with a ciliated corona, a trunk and a post-cloacal foot. Several rotiferan tissues are syncytial but musculature and nervous system are cellular $^{21}$. Muscles are mostly formed by few cells directly innervated by nerves formed by simple chains of single neurons $^{22}$. The excretory system consists of paired protonephridia with both cellular and syncytial sections ${ }^{21}$.

Phylogenomic approaches show that rotiferan sequences exhibit very high evolutionary rates resulting in unstable positions within calculated trees ${ }^{23-25}$. Likewise, Platyhelminthes and some ecdysozoans display fast evolving sequences. As a result, Rotifera are prone to long-branch-attraction (LBA) artifacts by grouping with e.g., Platyhelminthes. In addition, taxonomic sampling within Gnathifera is sparse. This has lead to the controversial hypothesis of a clade "Platyzoa" uniting Gnathifera with Platyhelminthes and Gastrotricha within Spiralia (Supplementary Fig. 1 $)^{26}, 27$. Recent phylogenomic approaches focusing on resolving spiralian phylogeny, though, support paraphyly of
Platyzoa and monophyly of Gnathifera placing Gnathifera basally near the Spiralia/Ecdysozoa split as sister to Lophotrochozoa and Rouphozoa (including Platyhelminthes and Gastrotricha) ${ }^{28-30}$.

Based on the presence of specific amino-acid residues and peptide motifs within the homeodomain and its flanking regions -referred to as signatures-Hox genes can be assigned to various paralogous groups (PG1-15) 31,32 . These paralogous groups are quite clearly defined for anterior class PG1-2, PG3 and median class PG4-5 Hox genes. Evolution of these Hox genes predates the divergence of Protostomia and Deuterostomia. Due to independendly duplicated median and posterior class Hox genes in different bilaterian lineages later on, the exact paralogy status of the remaining median genes (PG6-8) and posterior class genes (PG9-14) is more difficult to determine given the lack of diagnostic position and overall phylogenetic signal. However, these duplication events and subsequent selection present us with Hox gene orthologues along with their conserved amino-acid signatures characteristic for these specific lineages in the clades existing today, allowing us to examine phylogenetic relationships based on Hox gene complements and the Hox signatures within $^{33}$.

In this study, we isolate and examine genes of the Hox complement of the monogonont rotifer Brachionus manjavacas. Our analysis of Hox gene expression during embryogenesis of amictic females shows non-canonical expression patterns in the developing nervous system consistent with an original role of Hox genes in neurogenesis. Our sequence analyses show the presence of a new signature in the Hox6 paralog of B. manjavacas, shared by chaetognath Hox6 genes only. Furthermore, one of the rotifer Hox genes possesses median- and posterior-like amino-acid residues, exhibiting similarity to chaetognath MedPost genes. These results provide evidence for inclusion of both Rotifera and Chaetognatha in Gnathifera and also support a basal phylogenetic position of Gnathifera as sister group to the remaining Spiralia.

\section{Results}

Rotiferan Hox genes and metazoan phylogeny. We isolated single copies of five Hox genes from the monogonont rotifer Brachionus manjavacas. Based on phylogenetic analyses of the homeodomain and diagnostic amino-acid motifs, we assigned orthology of these genes to the anterior class Hox gene PG2 (Bm-Hox2), a PG3 gene (Bm-Hox3) and central class genes PG4 (Bm-Hox4) and PG6 (Bm-Hox6) (Supplementary Figs. 2, 3, 4, and 5). The fifth Hox gene isolated from Brachionus manjavacas surprisingly clusters with MedPost genes from the chaetognaths Flaccisagitta enflata and Spadella cephaloptera (Fig. 1a, Supplementary Figs. 3, 4, and 5) and is strongly supported with a posterior probability of $100 \%$ in Bayesian analysis. Maximumlikelyhood (ML) bootstrap support for this grouping is only $63 \%$, this, however, is comparable to the ML support of grouping of the ecdysozoan $A b d B$ genes (67\%) or all Saccoglossus kowalevskii Hox11-13 genes analyzed (61\%) and even higher than the support for grouping of all Lox5-genes undoubtedly related $(<50 \%)$ (Supplementary Fig. 5). Mean statistical support from ML analyses for Hox gene orthology assignments usually is significantly lower due to the highly conserved nature of the homeodomain ${ }^{34}$ While it could be argued that accelerated evolution could have led to phylogenetic artefacts as LBA, phylogenetic analyses did not reveal branch lengths for the grouping of the chaetognath and rotifer MedPost genes significantly larger than those observed for some posterior class Hox genes in general.

A careful examination of the homeodomain alignment of MedPost genes with either central class Hox genes or posterior class Hox genes (Supplementary Fig. 3) illustrates both, similarities and differences between rotiferan and chaetognath 
a

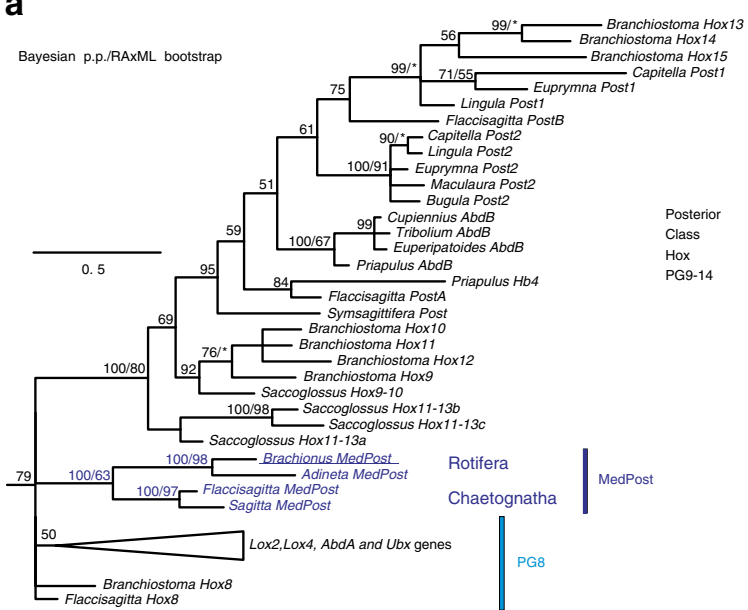

b

\begin{tabular}{|c|c|c|}
\hline & ${ }_{61} \cdots \mid \cdots 1_{70}$ & \\
\hline Tribolium antp & KTKGEGGSEG & Insecta \\
\hline Cupiennius antp & KAKEPAAGFI & Chelicerata \\
\hline Euperipatoides antp & KTKLPGSDSN & Onychophora \\
\hline Priapulus $\mathrm{Hb} 2$ & KARLIPNGDF & Priapulida \\
\hline Priapulus $\mathrm{Hb} 3$ & QAYGATCSTE & Priapulida \\
\hline Dugesia Plox5 & NIAKLTGPGS & Platyhelminthes \\
\hline Bugula Lox5 & NIAKLTGSEG & Bryozoa \\
\hline Lineus LsHox6 & NLQKLTGPNT & Nemertea \\
\hline Lingula Lox5 & NIPKLTGPNQ & Brachiopoda \\
\hline Euprymna Lox5 & NVSKLTGPDK & Mollusca/Cephalopoda \\
\hline Capitella Lox5 & NISKLTGPNG & Annelida/Polychaeta \\
\hline Helobdella Lox 5 & NVQKLTGPGG & Annelida/Hirudinea \\
\hline Flaccisagitta Hox 6 & NLKS INDAKP & Chaetognatha \\
\hline Brachionus Hox6 & NIKSLNDPSV & Rotifera/Monogononta \\
\hline Philodina Hox $6 \mathrm{c}$ & NFKSLNDPNV & Rotifera/Bdelloida \\
\hline Adineta Hox 6 & NFKSLNDPNV & Rotifera/Bdelloida \\
\hline Petromyzontidae Hox 6 & NIPSLSKEEC & Vertebrata \\
\hline Branchiostoma Hox6 & KIPSLNATTI & Cephalochordata \\
\hline Strongylocentrotus Hox 6 & NVKSISQLIS & Echinodermata \\
\hline Symsagittifera Central & NLKSMSQIDS & Acoela \\
\hline
\end{tabular}

C

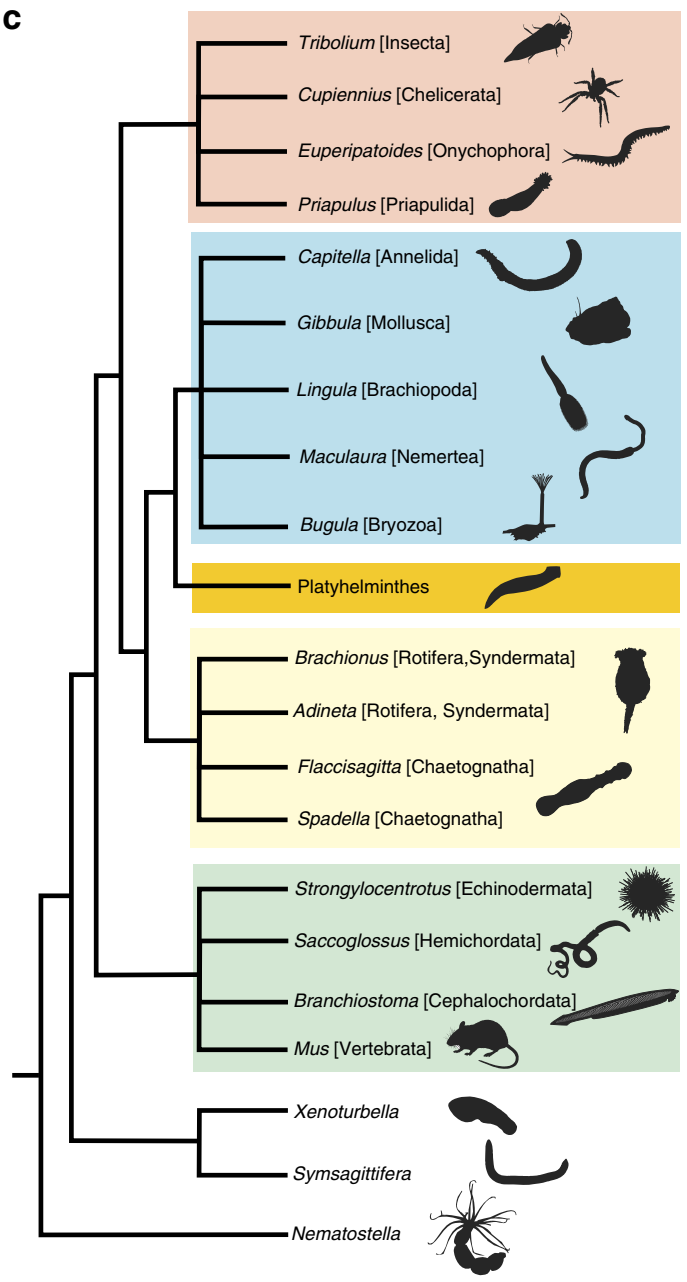

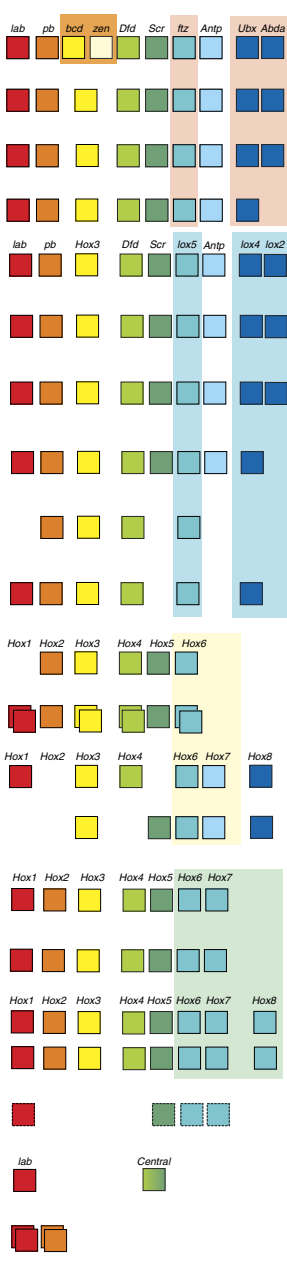

F




\begin{tabular}{|c|c|c|c|c|c|c|c|}
\hline & Chaetognatha & Rotifera & Micrognathozoa & Gnathostomulida & Gastrotricha & Platyhelminthes & Lophotrochozoa \\
\hline Tripartite body plan with & + & + & - & - & - & - & $-{ }^{a}$ \\
\hline $\begin{array}{l}\text { anus terminal of medial } \\
\text { body region }\end{array}$ & & & No anus & No anus & & No anus & \\
\hline $\begin{array}{l}\text { Additional major nerve } \\
\text { plexus in the trunk }\end{array}$ & + & + & - & - & - & - & - \\
\hline Lateral sensory antennae & + & + & - & - & - & - & - \\
\hline Trunk exterior cilitated & - & - & + & + & + & + & + \\
\hline $\begin{array}{l}\text { Complex chitinous } \\
\text { structures associated with } \\
\text { feeding }\end{array}$ & + & + & + & + & $(-)^{b}$ & (No chitin) & $(+)^{\mathrm{C}}$ \\
\hline Spiral cleavage & - & - & $?$ & + & - & + & + \\
\hline $4 \mathrm{~d}$ mesentoblast & - & - & $?$ & & - & + & + \\
\hline PGC specification & Preformation & Preformation & $?$ & & Epigenesis & $\begin{array}{l}\text { Epigenesis/ } \\
\text { preformation }\end{array}$ & $\begin{array}{l}\text { Mostly } \\
\text { epigenesis }\end{array}$ \\
\hline Trochophora larvae & - & $-d$ & $?$ & $?$ & - & + & + \\
\hline \multicolumn{8}{|l|}{ Hox cluster characteristics } \\
\hline $\begin{array}{l}\text { PG6 Hox signature } \\
\text { KS(I/L)ND }\end{array}$ & + & + & $?$ & ? & ? & - & - \\
\hline MedPost class Hox gene & + & + & ? & $?$ & ? & - & - \\
\hline
\end{tabular}

MedPost genes. Both groups share nine of eleven central class diagnostic amino acids: Q (position 6 of the homeodomain), LTR(R/K)RR (26-31) and E (59). Previous work on MedPost genes of Flaccisagitta enflata ${ }^{35}$ and Spadella cephaloptera ${ }^{36}$ defined diagnostic posterior class residues characteristic for chaetognath MedPost genes: K(3), A(14), R(18), Y(20) and V(21). Only two of these posterior class diagnostic residues, $\mathrm{K}(3)$ and $\mathrm{Y}(20)$ are shared between chaetognaths and rotifers, but clearly, they represent plesiomorphic characters since they are also present in posterior Hox genes of all major bilaterian clades and interestingly also in chaetognath Post $A$ and Post $B$ genes (Supplementary Fig. 3). The other amino-acid residues A(14), $\mathrm{R}(18)$, and $\mathrm{V}(21)$ present in chaetognaths but not in rotifers are neither found in posterior class Hox genes of Ecdysozoa nor in those of Deuterostomia, but surprisingly in Post1 genes typical of Lophotrochozoa (Supplementary Fig. 3). Amino-acid residues supposedly characteristic for a new gene class thus have to be re-evaluated once new genes sharing these characteristics have been isolated. MedPost genes in general might be defined by only some of the posterior class specific amino-acid positions while others might be specific for one of the taxa only. Hox genes belonging to the same paralogous group often exhibit diversity at some positions of the homeodomain (Supplementary Fig. 2). The presence of MedPost could also be interpreted as a possible ancestral character, but if it was lost in the Lophotrochozoan + Rouphozoan lineage chaetognaths could still be affiliated to gnathiferans.

The possible close relationship between Rotifera and Chaetognatha was further supported when the homeodomain and $3^{\prime}$ flanking sequences of the PG6 gene Bm-Hox6 were analyzed (Fig. 1b). Lophotrochozoans and Platyhelminthes possess some central class Hox genes containing amino-acid motifs not observed in ecdysozoan or deuterostome taxa. These genes have been named Lox5 (PG6/7), Lox2, and Lox4 (both PG8). Lox5 orthologs possess the motif "KLTGP" in the carboxy flanking region of the homeodomain. (position 64-68) 31,37 , and it seems likely that this motif was present in a common ancestor of Lophotrochozoa and a newly proposed clade Rouphozoa $^{30}$ consisting of Platyhelminthes and Gastrotricha. Importantly, the PG6 gene of $B$. manjavacas not only lacks this "Lox5-parapeptide", it possesses a new Hox signature "KS(I/L) ND" at position 63-67 also identified in PG6 genes of the bdelloid rotifers Philodina roseola and Adineta vaga, and the chaetognath Flaccisagitta enflata (Fig. 1b). This motif is not entirely identical among rotifers and chaetognaths, however, Hox signatures exhibit some variability as known from the variant Lox5 signature of Myzostomida ${ }^{38}$ and some Platyhelminthes ${ }^{39}$ or the Ubd-A peptide of Spiralia ${ }^{35}$. Recent phylogenomic approaches support Ecdysozoa as sister group to Spiralia, and neither ecdysozoan nor deuterostome PG6 genes possess a Hox signature in the carboxy flanking region to the homeodomain. Moreover PG6 Hox genes are absent in Xenacoelomorpha ${ }^{40-42}$ sister group to Nephrozoa (Deuterostomia, Ecdysozoa, and Spiralia) ${ }^{43}, 44$. Thus both signatures, the "Lox5-parapeptide" and the "KS(I/L)ND" signature could have evolved independently after the split of Ecdysozoa and Spiralia. The alternative hypothesis that the new signature is plesiomorphic has weaker support.

Consistent with their absence in the publically available genome of the bdelloid rotifer Adineta vaga ${ }^{45}$, PG8 genes (Lox2/Lox4/Ubx/AbdA) and posterior Hox genes (PG9-14) were not recovered from the monogonont rotifer $B$. manjavacas suggesting that these genes are missing in Rotifera (Fig. 1c). 
Another central class gene (PG5) has recently been recovered from the genome of Brachionus manjavacas while the presence of the second anterior class gene (PG1) as identified in $A$. vaga ${ }^{45}$ could not be confirmed (D. M. Welch, personal communication). Interestingly a single PG8 gene with similarity to ecdysozoan and lophotrochozoan PG8 genes and two posterior Hox genes sharing key residues with lophotrochozoans, ecdysozoans, and deuterostomes, have been isolated from the chaetognath F. enflata ${ }^{35}$. Posterior class Hox genes are also present in the cnidarian Nematostella vectensis ${ }^{34}$ and have been shown to exhibit extraordinary flexibility leading to possible independent evolution in different lineages ${ }^{46}$. Thus, the most parsimonous explanation is that both PG8 Hox genes and the posterior genes (PG9-14) have been lost in rotifers (Fig. 1c).

Some phylogenomic analyses found support for a group called Platyzoa consisting of Gnathifera, Gastrotricha, and Platyhelminthes ${ }^{23}, 24,47$, but morphological characteristics supporting this group have never been strong. All platyzoans are non-coelomate, ciliated animals with worm-like appearance without specialized respiratory or vascular systems $\mathrm{s}^{27}$. However, most platyzoans are microscopic and aquatic making diffusion an effective transport mechanism and vascular systems and respiratory organs are unnecessary. Developmental features uniting Platyhelminthes, namely spiral cleavage, resulting cell-lineage and the characteristic Müller's and Götte's larvae regarded to be modified trochophores can neither be found in gnathiferan taxa nor in gastrotrichs. Overall morphological synapomorphies supporting Platyzoa are hard to find.

The presence of a MedPost gene and the differing signature in the PG6 gene of rotifers and chaetognaths points to a close relationship, which is supported by several shared morphological and developmental traits (Table 1). Gnathifera, which is well supported by phylogenomic studies, is named after the presence of complex chitinous jaws used for feeding, which is found in Rotifera, Micrognathozoa, and Gnathostomulida ${ }^{15}$, 48, 49.

Even though chaetognaths do not possess internal structures quite comparable to the jaws of gnathiferans, both the high chitin content of the spines and teeth and the structure of the chitinous cuticle of the chaetognath head could be homologous to the chitinous parts and membranes of the pharynx in gnathiferans. Both chaetognaths and rotifers feature a tripartite body plan consisting of head, trunk without external motile cilia and foot/tail region. In contrast to Lophotrochozoa and Gastrotricha, the anus is not located terminally but instead near the posterior border of the medial region. Also the trunk regions of Lophotrochozoa and Gastrotricha are with motile cilia. The nervous system includes additional nerve plexi: the caudal ganglion in rotifers and the ventral ganglion in chaetognaths. Both also feature lateral sensory antennae connected to the nervous system. The corona, the ciliary organ of rotifers used for downstream collection of food particles, consists of compound cilia while the corona of chaetognaths is formed by a band of monociliate cells. Despite these structural differences, both are innervated by two coronal nerves. The mastax ganglion of rotifers is connected to the brain via two nerves. In chaetognaths, the suboesophageal ganglion is connected to the brain in a similar fashion with two small separate vestibular ganglia integrated in the nerves connecting to the brain. An additional pharyngeal ganglion has also been reported for Gnathostomulida ${ }^{50,51}$.

Embryonic development of Chaetognatha and Rotifera shares some important characteristics. Spiral cleavage, prevalent in Lophotrochozoa and Platyhelminthes, is absent in Rotifera and Chaetognatha. The latter two groups exhibit D-quadrant cleavage but do not form a $4 \mathrm{~d}$ mesentoblast. Primordial germ cells (PGCs) of rotifers and chaetognaths are specified by preformation only, in contrast to the specification of PGCs of Platyhelminthes and
Lophotrochozoa by mostly epigenesis ${ }^{52}$. Unfortunately, hardly anything is known about embryonic development of Micrognathozoa and only the earliest embryonic development has been described for a gnathostomulid species once, indicating possible presence of spiralian cleavage in this group ${ }^{53}$. Early cleavage patterns of chaetognaths and rotifers differ from each other. In chaetognaths, cleavage is total and equal forming a blastula. A typical invagination gastrula can be observed. This basic cleavage pattern had originally been mistaken as radial cleavage $54,55$. Rotifer development involves total and unequal first cleavages. Subsequently columns of cells descending from the A-C quadrant are formed by cleavage with mitotic spindles parallel to the primary axis. The $2 \mathrm{D}$ blastomere is then internalized by epibolic gastrulation $^{19}$. These differences do not necessarily contradict the hypothesis of unison of Chaetognatha and Gnathifera. Even within the morphologically and phylogenetically well supported Gnathifera very different cleavage modes can be observed. The development of the parasitic thorny-headed worms Acanthocephala is different from that reported for monogonont rotifers though both are in included in Syndermata ${ }^{56}$. The cleavage modes of rotifers and chaetognaths could, therefore, be interpreted as steps in a transformation series towards spiral cleavage with chaetognaths showing a more basal pattern.

These findings are consistent with the results of phylogenetic analyses based on EST data, mitochondrial genomes and tropomyosin where Chaetognatha is sister group to Lophotrochozoa $^{57}$ or sister group to Protostomia ${ }^{47}$, 58. Moreover, a phylogenomic study based on EST sequences of 197 genes from 66 metazoan species including both Rotifera and Chaetognatha but unfortunately lacking other gnathiferan groups supports this grouping, albeit weakly ${ }^{25}$. Newer phylogenetic studies that took LBA artefacts into account placed Gnathifera as sister to Lophotrochozoa and Rouphozoa but excluded chaetognaths from the analysis. Thus, both Rotifera and Chaetognatha were placed at the same position in different phylogenomic studies, indicating a possible close relationship of these taxa. Intriguingly, the newest phylogenomic study including Gnathostomulida, Rotifera, and Chaetognatha shows strong support for a clade including Gnathifera and Chaetognatha as sister to all lophotrochozoans after Bayesian analysis (posterior probability $=1.0$ ) and mediocre support for a clade formed by Gnathifera and Chaetognatha alone $(\mathrm{pp}=0.69)^{29}$.

Non-canonical expression of rotifer Hox genes. The most fascinating and highly conserved feature of Hox genes is the correlation of spatial expression along the anteroposterior axis with the structure of the genomic Hox cluster. This spatial collinearity results in the formation of nested Hox expression domains by shifting anterior borders of expression in the developing nervous system and other tissues ${ }^{4}$. Unique combinations of Hox genes activated within a body region specify that region's identity (Hox-code). Here, we report Hox gene expression patterns in Rotifera. During embryogenesis of the monogonont rotifer Brachionus manjavacas all five isolated Hox genes are expressed in parts of the nervous system and display unique expression patterns unrelated to anteroposterior axis formation (Figs. 2 and $3 \mathrm{a}$ ).

The anterior class Hox gene Brachionus manjavacas Hox2 $(B m-H o x 2)$ is expressed in cells forming the main ventrolateral nerves connecting the brain to the caudal ganglion, a secondary nerve centre at the base of the foot. Initially upregulated in a pair of cells on the ventral side of the embryo near the anterior pole at the beginning of morphogenesis, these $\mathrm{Bm}$-Hox2-positive cells move laterally and undergo cell divisions in an anterior-toposterior fashion resulting in paired nerve cords consisting of 
a

$\begin{array}{lll}\text { St. } 2 & \text { St. } 3 & \text { St. } 4\end{array}$

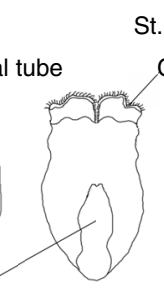

St. 5

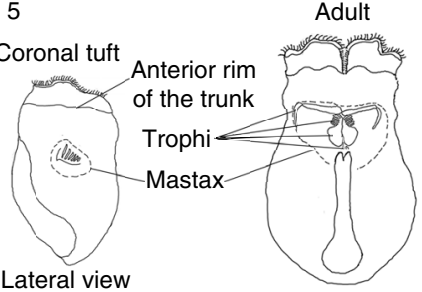

b
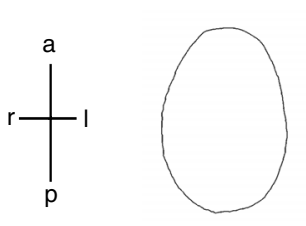

Mouth

Foot

Lateral view
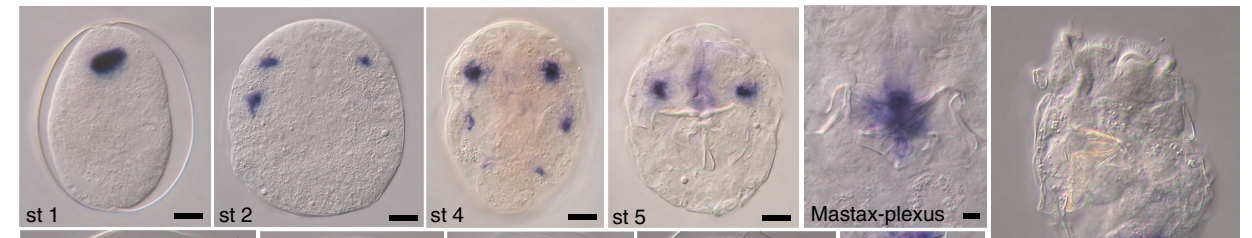

Bm-Hox3

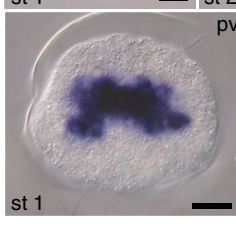

Bm-Hox4
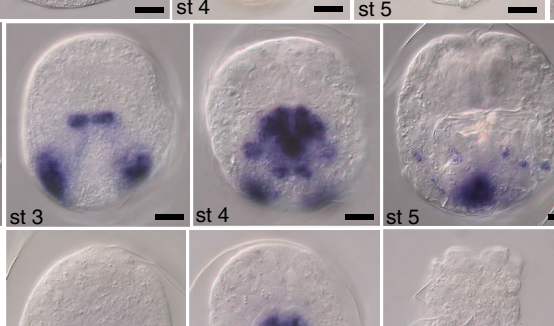

Bm Hox

Bm-Hox6

Bm-MedPost
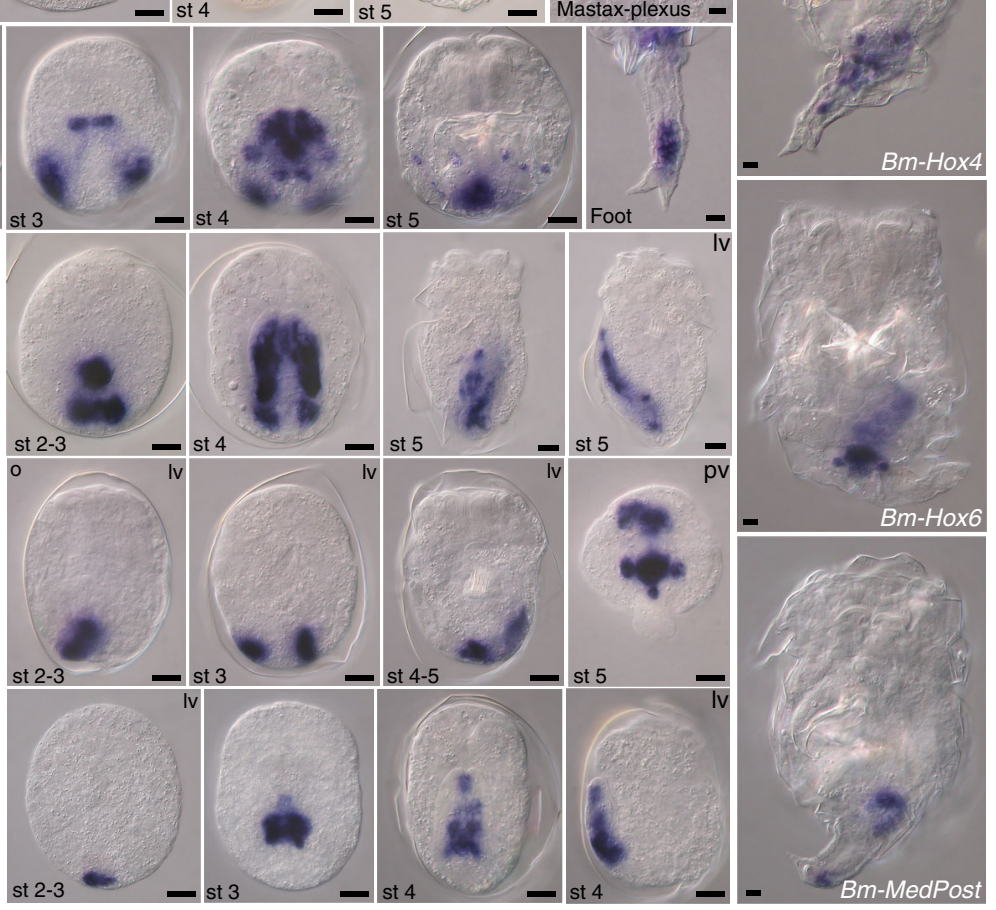

Fig. 2 Expression of Hox genes during embryogenesis of Brachionus manjavacas. a Schematic of embryonic stages of Brachionus manjavacas with morphological characteristics used for staging. b Whole-mount in situ hybridization on amictic female embryos. Adults are only shown for genes with expression persisting into the adult stage. Anterior to the top. Mostly ventral views are shown. pv, posterior view, dorsal side up; Iv, lateral view, ventral to the left. Scale bar, $10 \mu \mathrm{m}$

three interconnected neurons each (Fig. 2 and Supplementary Fig. 6a). Interestingly, anteroposterior patterning of the main longitudinal nerves by nested expression of several Hox genes does not occur. Faint expression of $B m-H o x 2$ is also detectable in the mastax plexus after hatching (Fig. 2 and Supplementary Fig. 6d, e), consistent with the observation of anterior Hox gene expression in structures associated with the stomatogastric nervous system in other taxa ${ }^{4}$. Expression of Hox genes in the rotifer brain or in the coronal nerves (Supplementary Fig. 6b, c) has not been detected.

Strikingly, most Hox orthologues (Bm-Hox3, Bm-Hox4, BmHox6, and Bm-MedPost) are expressed in a neurogenic region of the embryo near the posterior pole giving rise to morphological innovations: e.g., the caudal ganglion and foot primordium (Fig. 2). The central class gene Bm-Hox6 is expressed in the developing disc-shaped caudal ganglion originating from a single expression domain shifting inwards from the posterior pole of the embryo. Protruding laterally and ventrally the caudal ganglion resembles a clover leaf. Bm-Hox3 also participates in patterning of this secondary nerve centre. Bilateral symmetrical domains expressing Bm-Hox3 at the base of the forming foot fuse during morphogenesis and are integrated into the caudal ganglion. This ganglion serves as the control hub for the posterior part of the trunk providing neuromuscular control of the pedal muscles and innervation of the foot. Bm-Hox3 is also involved in patterning of the pedal nerves. An expression domain in the distal part of the foot primordium gives rise to six cells with neural morphology in the trunk region connecting to the caudal ganglion. The position of the labeled pericarya is consistent with the six horns of the pedal muscles in Brachionus. Remarkably, Bm-Hox6 was recruited to pattern an additional functional domain of the nervous system, forming an asymmetrical nerve loop on the dorsal left side of the animal connecting the single germovitellarium to the caudal ganglion (Supplementary Fig. 6a). This observation indicates neuronal control of the germovitellarium by or via the caudal ganglion.

The rotiferan foot is a remarkable structure enabling transient attachment to surfaces via a glue-like secretion. Expression of $\mathrm{Bm}$-Hox4 during foot formation marks cells in the proximal and 


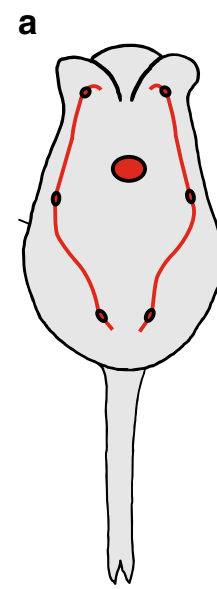

Bm-Hox2

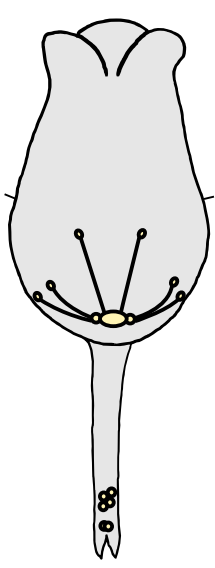

$\mathrm{Bm}-\mathrm{Hox} 3$

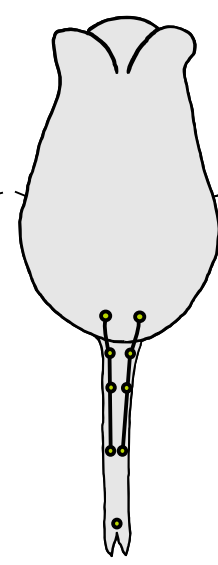

Bm-Hox4

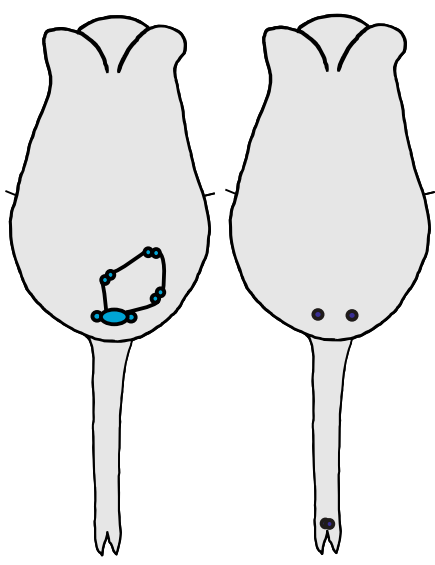

Bm-Hox6

Bm-MedPost

b

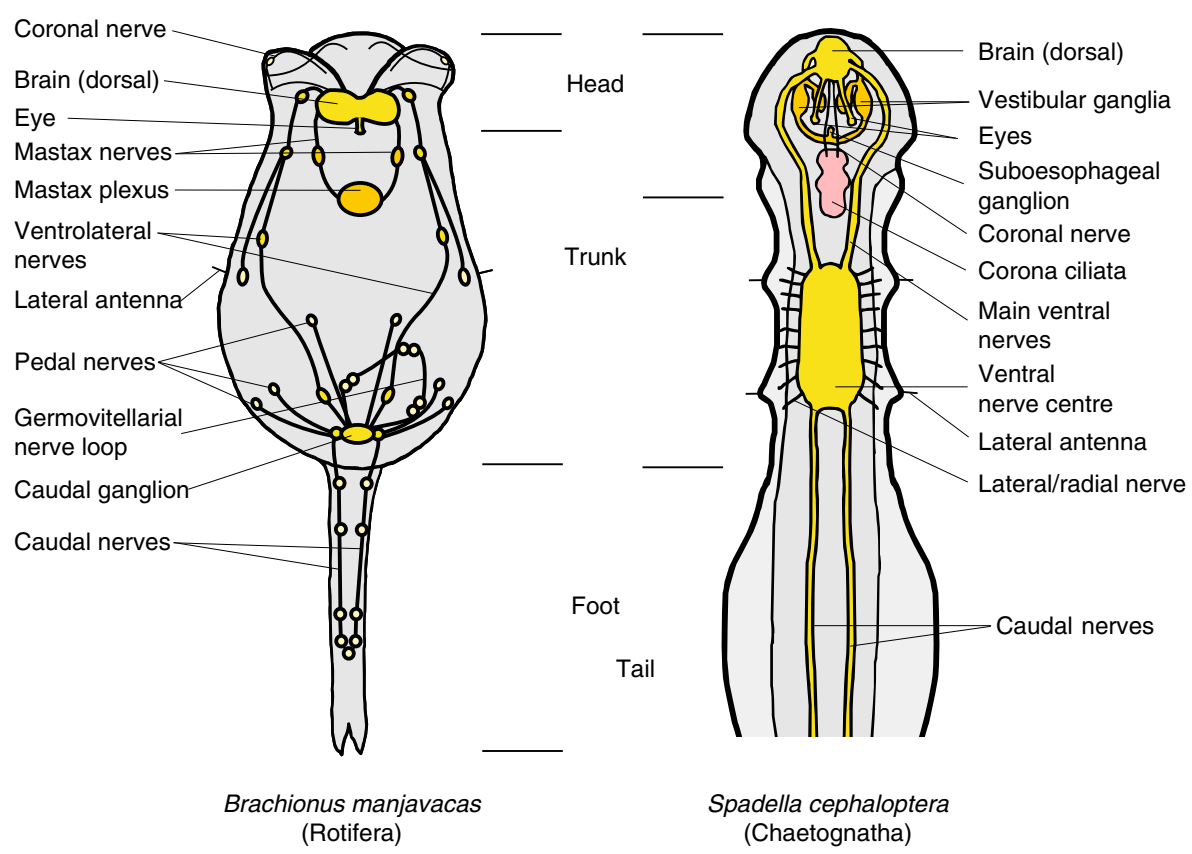

Fig. 3 Body plans and nervous systems in Rotifera and Chaetognatha. a Diagram of Hox gene expression in the nervous system of Brachionus manjavacas. b Comparison of rotiferan and chaetognath body plans with respect to the structure of the nervous system. Both groups have a dorsal brain and additional nerve plexi: mastax nerves and ganglia in rotifers and vestibular, and esophageal ganglia in chaetognaths as well as a caudal ganglion in rotifers and a ventral nerve centre in chaetognaths with the latter possibly incorporating functional subsets, these are still separated from the caudal ganglion in rotifers, e.g., innervation of sensory lateral antennae

central parts of the foot, giving rise to the caudal nerves and their connection to the caudal ganglion. Cells clustered at the tip of the foot have long been regarded to be simple gland cells ${ }^{21}$. Bm-Hox3, however, is strongly expressed in 12-14 cells connected to the caudal nerves and both Bm-Hox4 and Bm-MedPost exhibit overlapping expression in one or two cells at the base of the "toes". In deuterostomes, posterior class Hox genes play key roles in patterning of the postanal tail ${ }^{46}$. In rotifers, posterior class genes are missing, leaving the key role of modeling of the nervous system of the postanal foot to central and MedPost class Hox genes. Judging from the innervation of this body region with FMRFamide- and serotonin (5HT)-positive nerve cells (Supplementary Fig. 6f, g) and expression of several Hox genes in the foot, we conclude that secretion of the "glue" is under neuronal control and the cells in the foot might represent an additional nerve plexus.
As most rotifer tissues are syncytial, and nerves consist of only a few interconnected neurons ${ }^{21,22}$, code-like Hox expression is somewhat limited. This and newly evolved neuronal structures might have led to Hox gene regulation being adapted to modulate functional subsets of the rotifer nervous system (Fig. 3a). That the evolution of new and individual regulatory elements allowed the uncoupling of Hox expression from the constraints of collinearity is supported by the dispersed Hox cluster structure reported in the bdelloid rotifer Adineta vaga ${ }^{45}$. However, the genomic structure of a monogonont rotifer Hox cluster has not yet been published. Surprisingly, Hox gene expression in Brachionus manjavacas does not seem to violate spatial colinearity completely as the patterns observed exhibit shifting anterior borders of expression to some extent. Temporal colinearity has been reported for some taxa ${ }^{4}$, a correlation of the temporal order of Hox gene activation during embryogenesis with the order of 
Hox genes in a cluster. The rather rapid morphogenesis in rotifers complicates determination of the order of Hox gene activation in this case. In B. manjavacas, transcription of the anterior Hox gene $B m-H o x 2$ and $B m-H o x 3$ is indeed upregulated earlier (stage 1) than transcription of the other Hox genes (stage 2). The central class Hox genes analyzed are likely to be activated more or less simultaneously, but are all involved in patterning of the caudal ganglion and the nerves of the foot. Differing onsets of transcription may, therefore, be based on the order of morphological processes these genes are involved in rather than correlation with Hox cluster structure.

\section{Discussion}

Though not typically used for reconstructing phylogenies, analyses of Hox genes for diagnostic residues and conserved motifs give important phylogenetic clues. Patterning of animal body plans during ontogenesis is linked to the Hox gene complement in a very unique way. Major evolutionary changes of body plans have been accompanied and most probably have been made possible by changes of the Hox cluster structure ${ }^{6,8,59}$. Hox gene duplications enabled imprinting of additional positional information and thus evolution of additional body regions along the antero-posterior axes of animals. Reflected by possession of conserved amino-acid residues encoded in Hox genes these evolutionary changes and gene duplications seem to have happened independently in different clades. Hox genes play key roles in axial patterning and segment identity in many taxa. Our findings, however, suggest a different original role of Hox genes in metazoan evolution. In the diploblast metazoan Nematostella vectensis, Hox genes are predominantly expressed asymmetrically on one side of the body column of the polyp exhibiting slightly staggered epithelial expression patterns with large overlap ${ }^{34}$. Nematostella vectensis Hox genes are predominantly expressed in the endodermal layer. Neural expression has not been reported. Within triploblast metazoans, recent phylogenomic studies revealed a sister group relationship of Xenacoelomorpha (consisting of Acoela, Nemertodermatida, and Xenoturbella) and Nephrozoa (Deuterostomia and Protostomia) ${ }^{43}, 44$. Analyses of Hox gene expression in the acoel Convolutriloba longifissura indicate possible participation of acoel Hox genes in axial patterning of the nervous system due to subepidermal localization and coexpression with neural markers ${ }^{0}$. Consistent with morphological characteristics, phylogenomic analyses place Gnathifera near the base of Spiralia ${ }^{28-30}$. Rotifers possess a miniature but rather complex nervous system. Here Hox genes have been recruited to pattern the nervous system in a noncanonical way. Amazingly, rotiferan Hox genes show expression domains specifying functional subsets, with a strong bias in patterning of the caudal ganglion and the postanal foot as morphological novelties rather than exhibiting canonical Hox code expression along the anteroposterior axis. Unfortunately, Hox expression analysis has been reported for only a single chaetognath Hox gene ${ }^{61}$; however, expression of Spadella Hox4 in the ventral ganglion seems to be comparable to Bm-Hox4 expression in the caudal ganglion. These results might suggest an original role of Hox genes in neurogenesis. Consequently, their function in bauplan development would have been co-opted for other tissues during evolution.

Morphological or molecular ambiguities often lead to difficulties in phylogenetic placement of taxa. Several morphological traits strongly support Gnathifera. The support of a grouping of Rotifera and Chaetognatha based solely on either morphological traits (Fig. 3b) or developmental features may be weak; the combined analyses of morphology, development, and Hox sequences, however, provide an informative basis for this relationship. In addition, the newest and most comprehensive phylogenomic studies show some albeit moderate support of a close relationship of Gnathifera and Chaetognatha consistent with our results ${ }^{29}$. Though Hox gene information from Gnathostomulida and Micrognathozoa is currently not available, we expect these groups to show Hox characteristics consistent with this study. Exhibiting ambiguous characteristics indicating a possible close relationship to either Platyhelminthes or Gnathifera, placement of Gastrotricha has always been problematic. Phylogenomic approaches support both, a relationship with Platyhelminthes in Rouphozoa or a close relationship to Rotifera. Based on this study, we suggest an inclusion of chaetognaths in gnathiferans and Gnathifera as sister group to the remaining spiralians. The rather unusual expression of Hox genes in Brachionus manjavacas is additional evidence of this proposed phylogeny.

\section{Methods}

Collection of embryos. The rotifer Brachionus manjavacas (Florida Aqua Farms) was cultured in $15 \mathrm{ppm}$ artificial sea water (ASW, Tropic Marin Classic) at $24^{\circ} \mathrm{C}$ and fed Nannochloropsis microalgae culture in ASW (Florida Aqua Farms) twice a day. Animals were collected by sifting through a $50 \mu \mathrm{m}$ nylon mesh and washed briefly with fresh artificial seawater. After being anesthetized in $0.5 \mathrm{mM}$ Bupivacain in ASW for $12 \mathrm{~min}$, animals and embryos were subjected to prefixation in $0.5,1$, $1.5,2,3 \%$ formaldehyde in PBS pH 7.4 for 2 min each followed by $3.7 \%$ for $10 \mathrm{~min}$ at room temperature (RT). For permeabilization of the egg shell, specimens were sonicated in glass test tubes for $40 \mathrm{~s}$. Final fixation took place for $30 \mathrm{~min}$ at RT thereafter. Fixative was removed by washing 3-4 times with PTw $(1 \times \mathrm{PBS}$ pH 7.4 $0.1 \%$ Tween-20) for 5 min each, tissue was subsequently dehydrated by washing 3-4 times in methanol for $5 \mathrm{~min}$ each and stored at $-32^{\circ} \mathrm{C}$ until use.

In situ hybridization. Fixed rotifers and embryos were rehydrated briefly in a series of 75, 50, 25\% methanol in PTw followed by four washes in PTw for 5 min each. Tissue was permeabilized by treatment with $0.01 \mathrm{mg} \mathrm{ml}^{-1}$ proteinase $\mathrm{K}$ in PTw for 10 min on a shaker. Digestion was stopped by two 5 min washes with $2 \mathrm{mg} \mathrm{ml}^{-1}$ glycine in PTw. After transfer to $1 \%$ triethanolamine (TEA) in PTw, specimens were subjected to two treatments with $0.3 \%$ acetic anhydride in $1 \%$ TEA for $5 \mathrm{~min}$ each. After brief washes in PTw the tissue was refixed in $3.7 \%$

formaldehyde in PTw for $30 \mathrm{~min}$. Five washes with PTw were followed by a short preincubation in hybridization solution (HYBE: $50 \%$ formamide, $5 \times \mathrm{SSC} \mathrm{pH} 4.5$ $50 \mu \mathrm{g} \mathrm{ml}^{-1}$ heparin, $0.1 \%$ Tween-20, $1 \%$ SDS and $100 \mu \mathrm{g} \mathrm{ml}^{-1}$ salmon sperm DNA in diethyl pyrocarbonate (DEPC)-treated water) for $10 \mathrm{~min}$ at RT. Prehybridization in fresh hybridization solution was carried out over night at $65^{\circ} \mathrm{C}$. Tissues were hybridized with anti-sense riboprobes $\left(1-3 \mathrm{ng}^{-1}\right.$ ) at $65^{\circ} \mathrm{C}$ for $60 \mathrm{~h}$. Subsequently tissues underwent post-hybridization by washing with $\mathrm{HYBE}$ twice for 10 and 20 min at $65^{\circ} \mathrm{C}$, followed for $10 \mathrm{~min}$ each in $75 \% \mathrm{HYBE}$ and $25 \% 2 \times \mathrm{SSC}, 50 \% \mathrm{HYBE}$ and $50 \% 2 \times$ SSC, $25 \% \mathrm{HYBE}$ and $75 \% 2 \times$ SSC and $100 \% 2 \times$ SSC at $65^{\circ} \mathrm{C}$. Two 30 min washes in $0.05 \times \mathrm{SSC}$ at $65^{\circ} \mathrm{C}$ concluded posthybrization. Tissues were washed for $10 \mathrm{~min}$ each in $75 \% 0.05 \times \mathrm{SSC}$ and $25 \% \mathrm{PTw}, 50 \% 0.05 \times$ SSC and $50 \% \mathrm{PTw}$, $25 \% 0.05 \times$ SSC and $75 \%$ PTw and $100 \%$ PTw. Blocking was performed by washing five times for $10 \mathrm{~min}$ in PBT $(1 \times \mathrm{PBS}, \mathrm{pH} 7.4,0.2 \%$ Triton $\mathrm{X}-100,0.1 \%$ bovine serum albumin) and $1 \mathrm{~h}$ in $1 \times$ blocking buffer (Roche) in maleic acid buffer (100 mM maleic acid, $150 \mathrm{mM} \mathrm{NaCl}, \mathrm{pH}$ 7.5) at RT. For detection of the riboprobes tissues were incubated in anti-digoxygenin-AP Fab fragments (Roche) diluted 1:5000 in blocking buffer for $16 \mathrm{~h}$ over night at $6^{\circ} \mathrm{C}$ on a shaker followed by ten washes for $10 \mathrm{~min}$ in PBT at RT. Expression patterns were visualized by three washes in AP buffer (100 mM NaCl, $50 \mathrm{mM} \mathrm{MgCl}_{2}, 100 \mathrm{mM}$ Tris $\mathrm{pH} 9.5,0.5 \%$ Tween-20) and detection with NBT/BCIP in AP-buffer as substrate. Specimens were analyzed using differential interference contrast optics on an Olympus BX-51 microscope. Digital photomicrographs were captured with a Nikon Coolpix 4500 digital camera (4.0 megapixel).

Cloning of Brachionus manjavacas Hox genes. Initially, small fragments of the homeodomain region of Brachionus manjavacas Hox genes were amplified by degenerate primer PCR. Different primer sets more or less specific for Hox genes in general or Hox genes belonging to specific PGs in particular (Supplementary Table 1) were used to isolate Hox gene fragments from either mixed stage complementary DNA (cDNA) or genomic DNA (gDNA). In the latter case, presence of introns within the homeodomain was taken into account. gDNA was isolated with an ArchivePure gDNA kit (5prime), cDNA was obtained by RNA isolation (RNeasy kit, Qiagen) followed by reverse transcription (RevertAid First Strand cDNA Synthesis Kit, Thermo Fisher Scientific). Genes were preliminarily identified by BLASTX search (NCBI). Large fragments of cDNAs suitable for phylogenetic analysis and riboprobe synthesis were obtained by RACE (rapid amplification of cDNA ends) with gene specific primers using the SmartRACE Kit (Clontech). All 
fragments were cloned into pGEM-Teasy vector (Promega) and sequenced at Macrogen Inc (South Korea) or StarSeq (Germany).

Riboprobe synthesis. Digoxigenin-labeled riboprobes were generated by in vitro transcription using MEGAscript High Yield SP6 or T7 transcription kits (Ambion) with PCR products of suitables clones flanked by SP6- or T7 RNA polymerase promotor sites as templates.

Orthology assignment and phylogenetic analyses. Assignment to paralog groups (PG) was based on the phylogenetic analyses as well as the presence or absence of diagnostic amino-acid residues or motifs in homeodomain or flanking region of Hox genes, commonly regarded as apomorphies for specific PGs and even specific taxonomic groups.

For phylogenetic analyses sequences including the homeodomain and 12 amino acids of the carboxy flanking region next to the homeodomain were aligned using MacVector 8.0. Genome accession numbers of Adineta vaga Hox genes and Genbank accession numbers of all other Hox gene sequences used in phylogenetic analyses are given in Supplementary Table 2. The most suitable amino-acid substitution model LG $+\Gamma+$ I was determined by ProtTest $3.4^{62}$. Bayesian phylogenetic analyses were conducted with MrBayes V3.2.6 $6^{63,64}$ on the tera-grid accessible via the CIPRES science gateway V3.3 ${ }^{65}$. LG with invgamma was selected with $100 \%$ posterior probability with four independent runs of $10,000,000$ generations sampled every 100 generations and four chains each. A summary tree was generated from the final 300,000 trees. ML bootstrap analysis was conducted with RAxML-HPC v8.2.966 on XSEDE via the CIPRES science gateway V3.3 with 1000 iterations using the $L G+\Gamma+I$ model of protein evolution. Final trees were drawn using Figtree 1.4.2 (http://tree.bio.ed.ac.uk/software/figtree/) and CorelDraw 12. Nexus alignments are available upon request.

Data availability. Additional data associated with this study are available in the Supplementary Information of this publication. Assembled sequences for all Hox genes isolated from Brachionus manjavacas have been deposited with GenBank under accession numbers KT989538 (Bm-Hox2), KT989539 (Bm-Hox3), KT989540 (Bm-Hox4), KT989541 (Bm-Hox6), and KT989542 (Bm-MedPost). The amino-acid sequence of Bm-Hox5 is available in the Figshare Repository under the identifier $10.6084 / \mathrm{m} 9$.figshare.4616125.

Received: 29 June 2016 Accepted: 16 February 2017

Published online: 04 April 2017

\section{References}

1. Lewis, E. B. A gene complex controlling segmentation in Drosophila. Nature 276, 565-570 (1978)

2. Dessain, S., Gross, C. T., Kuziora, M. A. \& McGinnis, W. Antp-type homeodomains have distinct DNA binding specificities that correlate with their different regulatory functions in embryos. EMBO. J. 11, 991-1002 (1992).

3. Averof, M. \& Akam, M. Hox genes and the diversification of insect and crustacean body plans. Nature 376, 420-423 (1995).

4. Fröbius, A. C., Matus, D. Q. \& Seaver, E. C. Genomic organization and expression demonstrate spatial and temporal Hox gene colinearity in the lophotrochozoan Capitella sp. I. PLoS ONE 3, e4004 (2008).

5. Kourakis, M. J. \& Martindale, M. Q. Hox gene duplication and deployment in the annelid leech Helobdella. Evol. Dev. 3, 145-153 (2001).

6. Burke, A. C., Nelson, C. E., Morgan, B. A. \& Tabin, C. Hox genes and the evolution of vertebrate axial morphology. Development 121, 333-346 (1995).

7. Carroll, S. B. Homeotic genes and the evolution of arthropods and chordates. Nature 376, 479-485 (1995).

8. Averof, M. \& Patel, N. H. Crustacean appendage evolution associated with changes in Hox gene expression. Nature 388, 682-686 (1997).

9. Boncinelli, E., Simeone, A., Acampora, D. \& Gulisano, M. Homeobox genes in the developing central nervous system. Ann. Genet-Paris 36, 30-37 (1993).

10. Cameron, R. A. et al. Unusual gene order and organization of the sea urchin hox cluster. J. Exp. Zool. B. 306, 45-58 (2006)

11. Pierce, R. J. et al. Evidence for a dispersed Hox gene cluster in the platyhelminth parasite Schistosoma mansoni. Mol. Biol. Evol. 22, 2491-2503 (2005)

12. Edvardsen, R. B. et al. Remodelling of the homeobox gene complement in the tunicate Oikopleura dioica. Curr. Biol. 15, R12-R13 (2005).

13. Struhl, G. Splitting the bithorax complex of Drosophila. Nature 308, 454-457 (1984).

14. Von Allmen, G. et al. Splits in fruitfly Hox gene complexes. Nature 380, 116 (1996).

15. Kristensen, R. M. \& Funch, P. Micrognathozoa: a new class with complicated jaws like those of Rotifera and Gnathostomulida. J. Morphol. 246, 1-49 (2000).
16. Funch, P., Sørensen, M. V. \& Obst, M. On the phylogenetic position of Rotifera - have we come any further? Hydrobiologia 546, 11-28 (2005).

17. Sørensen, M. V. Further structures in the jaw apparatus of Limnognathia maerski (Micrognathozoa), with notes on the phylogeny of the Gnathifera. J. Morphol. 255, 131-145 (2003).

18. Jennings, H. S. The early development of Asplanchna herrickii de Guerne. A contribution to developmental mechanics. Bull. Mus. Comp. Zool. Harv 30, 1-117 (1896)

19. Lechner, M. Untersuchungen zur Embryonalentwicklung des Rädertieres Asplanchna girodi de Guerne. Roux's Arch. Entwicklungsmech. Org. 157, 117-173 (1966).

20. Nachtwey, R. Untersuchungen über die Keimbahn, Organogenese und Anatomie von Asplanchna priodonta Gosse. Z. Wiss. Zool. 126, 239-492 (1925).

21. Clément, P. \& Wurdak, E in Microscopic Anatomy of Invertebrates Vol. 4 (eds Harrison, F. W. \& Ruppert, E. E.) 219-297 (Wiley-Liss, 1991).

22. Clément, P. \& Amsellem, J. The skeletal-muscles of rotifers and their innervation. Hydrobiologia 186, 255-278 (1989).

23. Dunn, C. W. et al. Broad phylogenomic sampling improves resolution of the animal tree of life. Nature 452, 745-749 (2008).

24. Hejnol, A. et al. Assessing the root of bilaterian animals with scalable phylogenomic methods. Proc. R. Soc. B 276, 4261-4270 (2009).

25. Philippe, H. et al. Acoelomorph flatworms are deuterostomes related to Xenoturbella. Nature 470, 255-258 (2011).

26. Giribet, G., Distel, D. L., Polz, M., Sterrer, W. \& Wheeler, W. C. Triploblastic relationships with emphasis on the acoelomates and the position of Gnathostomulida, Cycliophora, Plathelminthes, and Chaetognatha: a combined approach of $18 \mathrm{~S}$ rDNA sequences and morphology. Syst. Biol. 49, 539-562 (2000).

27. Cavalier-Smith, T. A revised six-kingdom system of life. Biol. Rev. Camb. Philos. Soc. 73, 203-266 (1998).

28. Laumer, C. E. et al. Spiralian phylogeny informs the evolution of microscopic lineages. Curr. Biol. 25, 2000-2006 (2015).

29. Kocot, K. M. et al. Phylogenomics of Lophotrochozoa with consideration of systematic error. Syst. Biol. doi:10.1093/sysbio/syw079 (2016).

30. Struck, T. H. et al. Platyzoan paraphyly based on phylogenomic data supports a noncoelomate ancestry of Spiralia. Mol. Biol. Evol. 31, 1833-1849 (2014).

31. de Rosa, R. et al. Hox genes in brachiopods and priapulids and protostome evolution. Nature 399, 772-776 (1999).

32. Telford, M. J. Turning Hox "signatures" into synapomorphies. Evol. Dev. 2 360-364 (2000).

33. Balavoine, G., de Rosa, R. \& Adoutte, A. Hox clusters and bilaterian phylogeny. Mol. Phylogenet. Evol. 24, 366-373 (2002).

34. Ryan, J. F. et al. Pre-bilaterian origins of the Hox cluster and the Hox code: evidence from the sea anemone, Nematostella vectensis. PLoS ONE 2, e153 (2007).

35. Matus, D. Q., Halanych, K. M. \& Martindale, M. Q. The Hox gene complement of a pelagic chaetognath, Flaccisagitta enflata. Integr. Comp. Biol. 47, 854-864 (2007).

36. Papillon, D., Perez, Y., Fasano, L., Le Parco, Y. \& Caubit, X. Hox gene survey in the chaetognath Spadella cephaloptera: evolutionary implications. Dev. Genes. Evol. 213, 142-148 (2003).

37. Passamaneck, Y. J. \& Halanych, K. M. Evidence from Hox genes that bryozoans are lophotrochozoans. Evol. Dev. 6, 275-281 (2004).

38. Bleidorn, C., Lanterbecq, D., Eeckhaut, I. \& Tiedemann, R. A PCR survey of Hox genes in the myzostomid Myzostoma cirriferum. Dev. Genes. Evol. 219 211-216 (2009).

39. Orii, H. et al. The planarian HOM HOX homeobox genes (Plox) expressed along the anteroposterior axis. Dev. Biol. 210, 456-468 (1999).

40. Fritzsch, G. et al. PCR survey of Xenoturbella bocki Hox genes. J. Exp. Zool. B Mol. Develop. evol. 310, 278-284 (2008).

41. Jimenez-Guri, E., Paps, J., Garcia-Fernandez, J. \& Salo, E. Hox and ParaHox genes in Nemertodermatida, a basal bilaterian clade. Int. J. Dev. Biol. 50, 675-679 (2006)

42. Cook, C. E., Jimenez, E., Akam, M. \& Salo, E. The Hox gene complement of acoel flatworms, a basal bilaterian clade. Evol. Dev. 6, 154-163 (2004).

43. Cannon, J. T. et al. Xenacoelomorpha is the sister group to Nephrozoa. Nature 530, 89-93 (2016)

44. Rouse, G. W., Wilson, N. G., Carvajal, J. I. \& Vrijenhoek, R. C. New deep-sea species of Xenoturbella and the position of Xenacoelomorpha. Nature 530, 94-97 (2016).

45. Flot, J. F. et al. Genomic evidence for ameiotic evolution in the bdelloid rotifer Adineta vaga. Nature 500, 453-457 (2013).

46. Ferrier, D. E., Minguillon, C., Holland, P. W. \& Garcia-Fernandez, J. The amphioxus Hox cluster: deuterostome posterior flexibility and Hox 14. Evol. Dev 2, 284-293 (2000).

47. Marletaz, F. et al. Chaetognath transcriptome reveals ancestral and unique features among bilaterians. Genome Biol. 9, R94 (2008). 
48. Ahlrichs, W. H. Epidermal ultrastructure of Seison nebaliae and Seison annulatus, and a comparison of epidermal structures within the Gnathifera. Zoomorphology 117, 41-48 (1997).

49. Ahlrichs, W. H. Ultrastruktur und Phylogenie von Seison nebaliae (Grube 1859) und Seison annulatus (Claus 1876) (Dissertation, Georg-August-University, Göttingen, Cuvillier Verlag, 1995).

50. Kristensen, R. M. \& Nørrevang, A. On the fine structure of Rastrognathia macrostoma gen. et sp. n. placed in Rastrognathiidae fam. $\mathrm{n}$. (Gnathostomulida). Zool. Scr. 6, 27-41 (1977).

51. Müller, M. C. M. \& Sterrer, W. Musculature and nervous system of Gnathostomula peregrina (Gnathostomulida) shown by phalloidin labeling, immunohistochemistry, and cLSM, and their phylogenetic significance. Zoomorphology 123, 169-177 (2004).

52. Extavour, C. G. Evolution of the bilaterian germ line: lineage origin and modulation of specification mechanisms. Integr. Comp. Biol. 47, 770-785 (2007).

53. Riedl, R. J. Gnathostomulida from America. Science 163, 445-452 (1969).

54. Shimotori, T. \& Goto, T. Establishment of axial properties in the arrow worm embryo, Paraspadella gotoi (Chaetognatha): Developmental fate of the first two blastomeres. Zool. Sci. 16, 459-469 (1999).

55. Shimotori, T. \& Goto, T. Developmental fates of the first four blastomeres of the chaetognath Paraspadella gotoi: Relationship to protostomes. Dev. Growth Differ. 43, 371-382 (2001).

56. Schmidt, G. D. in Biology of the Acanthocephala (eds Crompton, D.W.T. \& Nickol B. B.) 273-305 (Cambridge University Press, 1985).

57. Matus, D. Q. et al. Broad taxon and gene sampling indicate that chaetognaths are protostomes. Curr. Biol. CB. 16, R575-R576 (2006).

58. Marletaz, F. et al. Chaetognath phylogenomics: a protostome with deuterostome-like development. Curr. Biol. CB. 16, R577-R578 (2006).

59. Lee, P. N., Callaerts, P., De Couet, H. G. \& Martindale, M. Q. Cephalopod Hox genes and the origin of morphological novelties. Nature 424, 1061-1065 (2003).

60. Hejnol, A. \& Martindale, M. Q. Coordinated spatial and temporal expression of Hox genes during embryogenesis in the acoel Convolutriloba longifissura. BMC. Biol. 7, 65 (2009).

61. Papillon, D., Perez, Y., Fasano, L., Le Parco, Y. \& Caubit, X. Restricted expression of a median Hox gene in the central nervous system of chaetognaths. Dev. Genes Evol. 215, 369-373 (2005).

62. Darriba, D., Taboada, G. L., Doallo, R. \& Posada, D. ProtTest 3: fast selection of best-fit models of protein evolution. Bioinformatics 27, 1164-1165 (2011).

63. Ronquist, F. \& Huelsenbeck, J. P. MrBayes 3: Bayesian phylogenetic inference under mixed models. Bioinformatics 19, 1572-1574 (2003).

64. Huelsenbeck, J. P. \& Ronquist, F. MRBAYES: Bayesian inference of phylogenetic trees. Bioinformatics 17, 754-755 (2001).
65. Miller, M. A., Pfeiffer, W. \& Schwartz, T. Creating the CIPRES Science Gateway for inference of large phylogenetic trees. in Proceedings of the Gateway Computing Environments Workshop (GCE). New Orleans, LA, 1-8 (2010).

66. Stamatakis, A. RAxML version 8: a tool for phylogenetic analysis and post-analysis of large phylogenies. Bioinformatics 30, 1312-1313 (2014).

\section{Acknowledgements}

We wish to thank David S. Richardson for valuable comments on the manuscript We gratefully acknowledge Andreas Vilcinskas and Adriaan W.C. Dorresteijn for support of the project.

\section{Author contributions}

P.F. initially conceived the project. A.C.F. oversaw the project and performed acquisition, analysis, and interpretation of the data including cloning of the Hox genes, staging of morphogenesis of Brachionus, analysis of gene expressing patterns and phylogenetic analyses. A.C.F. wrote the first draft of the paper and generated the figures. P.F. made substantial contributions to revisions of the draft of the article. Both authors discussed the results and commented on the manuscript.

\section{Additional information}

Supplementary Information accompanies this paper at doi:10.1038/s41467-017-00020-w.

Competing interests: The authors declare no competing financial interests.

Reprints and permission information is available online at http://npg.nature.com/ reprintsandpermissions/

Publisher's note: Springer Nature remains neutral with regard to jurisdictional claims in published maps and institutional affiliations.

(c) (i) This work is licensed under a Creative Commons Attribution 4.0 International License. The images or other third party material in this article are included in the article's Creative Commons license, unless indicated otherwise in the credit line; if the material is not included under the Creative Commons license, users will need to obtain permission from the license holder to reproduce the material To view a copy of this license, visit http://creativecommons.org/licenses/by/4.0/

(c) The Author(s) 2017 